\title{
The role of values in collaborative consumption: insights from a product-service system for lending and borrowing in the UK
}

\author{
Laura Piscicelli $^{\mathrm{a}, *}$, Tim Cooper ${ }^{\mathrm{a}}$, Tom Fisher ${ }^{\mathrm{b}}$ \\ a Nottingham Trent University, School of Architecture, Design and the Built Environment, Burton Street, NG1 4BU Nottingham, UK \\ ${ }^{\mathrm{b}}$ Nottingham Trent University, School of Art and Design, Burton Street, NG1 4BU Nottingham, UK
}

\section{A R T I C L E I N F O}

Article history:

Received 20 March 2013

Received in revised form

10 July 2014

Accepted 14 July 2014

Available online $\mathrm{xxx}$

\section{Keywords:}

Collaborative consumption

Pro-environmental behaviour change

Product-service systems

Social practice theory

Social psychology

Values

\begin{abstract}
A B S T R A C T
Collaborative consumption is an emerging socio-economic model based on sharing, renting, gifting, bartering, swapping, lending and borrowing. Made possible through community interaction and, increasingly, use of network technologies, these alternative and more sustainable ways of consuming have attracted growing attention for their potential to prevent new purchases, intensify the use of idle assets and promote reuse of possessions that are no longer wanted. Nonetheless, the uptake of ProductService Systems (PSSs) that enable collaborative consumption is still very limited. This paper investigates how consumers' values can influence the acceptance, adoption and diffusion of collaborative consumption. It reviews two theoretical frameworks used to understand pro-environmental behaviour, social psychological models of behaviour and social practice theory. Coming from contrasting disciplinary perspectives, these approaches conceptualise values differently. The paper evaluates the possibility of resolving these differences through a mixed methods study. It examines values empirically through a case study of Ecomodo, a UK-based online marketplace where people can lend and borrow each other's objects, spaces and skills, and present the results of a quantitative study which identified and measured value priorities among Ecomodo users through Schwartz's Portrait Value Questionnaire. It concludes with a discussion of the role of values in relation to the introduction and scaling up of PSSs that enable collaborative consumption.
\end{abstract}

๑) 2014 Elsevier Ltd. All rights reserved.

\section{Introduction}

Current patterns and levels of consumption in industrial economies are widely recognised as unsustainable ( $c f$. Tukker et al., 2006). Over-consumption and a throwaway culture are liable for major environmental problems such as resource depletion and waste. A possible solution to prevent unnecessary use of resources and excessive waste is to reduce new purchases and promote the reuse of products. Collaborative consumption ${ }^{1}-$ a socio-economic model based on the shared usage of some kind of commodities illustrates how it is possible to avoid, or at least delay, waste by bartering, swapping, gifting, renting, trading, lending and borrowing multiple, underused or unwanted goods between groups of individuals (Botsman and Rogers, 2011). Made possible through community interaction and, increasingly, use of network

\footnotetext{
* Corresponding author.

E-mail addresses: laura.piscicelli@ntu.ac.uk (L. Piscicelli), t.h.cooper@ntu.ac.uk (T. Cooper), tom.fisher@ntu.ac.uk (T. Fisher).

1 Also referred to as the 'sharing economy', or 'collaborative economy'.

technologies, collaborative consumption has grown in such a way that sharing has been described as having turned from a private or local behaviour into a transformational movement able to disrupt traditional business models (Owyang et al., 2014). Well known examples include eBay, Airbnb, TaskRabbit, BlaBlaCar, Uber, and Zipcar.

These innovative business models are largely enabled and performed by means of Product-Service Systems (PSSs): a specific type of value proposition oriented to fulfil needs and provide satisfaction to consumers (or 'users') through the delivery of an integrated system of products and services (Vezzoli et al., 2012). PSSs that enable collaborative consumption can be generally classified as 'use-oriented' and 'result-oriented' services (Tukker and Tischner, 2006a), providing access to products that remain owned by a company (e.g. bike and car sharing schemes, launderettes) or making privately owned possessions available to other people within a community (e.g. ridesharing, clothes swapping, peer-topeer accommodation). In most cases, these PSSs offer an enabling platform or a final result instead of a traditional product, thus representing a novel way of fulfilling a certain function (Manzini et al., 2001). 
For their capacity to bring economic interests in line with positive social and environmental impacts, sustainable PSSs have gained much attention in recent years as a promising pattern towards more sustainable consumption ( $c f$. Tukker and Tischner, 2006b). By creating value out of shared resources, PSSs that enable collaborative consumption shift the focus from individual private ownership of material goods to access and more efficient usage of pooled assets. This creates opportunities for development of new (and conceivably profitable business) propositions with potentially lower environmental impact and providing more meaningful experiences to users. For example, ridesharing stands as an opportunity to reduce car-running costs and negative environmental consequences but, also, to meet new people while travelling or daily commuting. Finally, due to its reliance on social networks and interactions, collaborative consumption may promote social innovation and contribute to building stronger and more connected communities.

Despite some successful cases and the untapped potential of peer-to-peer sharing, the phenomenon is in its infancy and the uptake of PSSs that enable collaborative consumption on the market is still very limited. Inadequate acceptance, adoption and diffusion has prevented such alternative forms of consuming from becoming mainstream. Also, exploratory research suggests that a number of start-ups have collapsed (e.g. ShareSomeSugar.com, Kashless.org) and many others are encountering serious difficulties in establishing themselves due to a lack of resources to scale-up (e.g. consumer base, money, trusted brand) (Owyang et al., 2014). One reason for this situation may be the concerted challenge that the sharing economy presents to existing consumer/user habits, company business models and regulatory frameworks. Alternative patterns of consumption require a radical change in practices from individuals, business communities, policy makers and society-atlarge. Renewed academic attention on the lack of wide implementation and dissemination of sustainable PSSs demonstrates the need to gain more insightful and useful knowledge on how consumers, in particular, can influence the process of introduction and scaling up of these propositions ( $c f$. Vezzoli et al., 2012).

The aim of the research project which informed and provided data for this paper was to investigate different ways of thinking about how values may contribute to the acceptance, adoption and diffusion of PSSs that enable collaborative consumption. The findings reported here are from the first phase of the study, which sought to identify values associated with engagement in collaborative consumption. Locating an overall context for the research project in pro-environmental behaviour change, the next section reviews two different approaches to understanding the role of values in the context of sustainable consumption, comparing aspects of social psychological models of pro-environmental behaviour with social practice theory. Section 3 presents an empirical study of Ecomodo, an online sharing platform, and explains how it is used to consider relationships between the concept of 'values' found in social psychology with that of 'meaning' found in social practice theory. In following sections, results from the initial, quantitative, strand of research are presented and discussed. These findings are used to draw some preliminary conclusions in Section 6 , which sets the scene for a subsequent strand of qualitative research that will be reported in a future paper.

\section{Theoretical frameworks to pro-environmental behaviour change}

In the context of sustainability, understanding consumer behaviour and how to bring about change is deemed essential to reduce the environmental impact of consumption. Grounded in the social sciences, different disciplinary perspectives offer distinct, if not contrasting, accounts to conceptualise pro-environmental behaviour change. Much academic literature and contemporary policy interventions either draw on social psychological models of consumer behaviour or sociological theories of practice.

\subsection{Social psychological models of consumer behaviour}

Social psychological models of consumer behaviour provide frameworks to understanding what motivates behaviour and drive its change. These models are built from different sets of conceptual premises and assumptions (for a comprehensive literature review refer to Jackson, 2005; Darnton, 2008). In 'rational choice models', for example, consumers are believed to make decisions between different courses of action by calculating individual costs and benefits, thus selecting the option that maximises their expected net benefits. 'Adjusted expectancy value theories' (e.g. Ajzen and Fishbein's Theory of Reasoned Action; Ajzen's Theory of Planned Behaviour) attempt to overcome some limitations of rational choice models by accounting for the psychological antecedents of consumer preferences. Moral and normative considerations are, instead, explicitly recognised as driver of pro-environmental or pro-social behaviour in a number of later models (e.g. Schwartz's Norm Activation Theory; Stern's Value-Belief-Norm Theory; Cialdini's Focus Theory of Normative Conduct).

While these models mainly focus on cognitive processes and determinants of behaviour that are internal to the individual, 'integrative theories of consumer behaviour' (e.g. Stern's AttitudeBehaviour-Context Model; Triandis' Theory of Interpersonal Behaviour; Bagozzi's Comprehensive Model of Consumer Action) add external elements (e.g. fiscal and regulatory incentives, institutional constraints, and social norms) in order to provide a more complete view (Jackson, 2005). Stern (2000), in particular, considers attitudinal (e.g. values, attitudes, beliefs), contextual or situational factors (e.g. interpersonal influences, government regulations, financial cost), personal capabilities (e.g. knowledge, skills, resources) and habits or routines as the four major types of causal variables either driving or hindering pro-environmental behaviour. However, the type and number of determinants that can be actually included in an empirical model is limited and it has to account for the complexity of contributing factors while balancing between parsimony and explanatory/predictive power of the proposed model (Jackson, 2005).

Policy interventions aimed at supporting more sustainable behaviours have been traditionally informed by social psychological understandings of individual attitudes and behaviour ( $c f$. Collier et al., 2010). Strategies put in place largely attempt to remove possible barriers to behaviour change and encourage consumers, seen as autonomous decision makers, to undertake a desired course of action by re-framing their attitudes and providing them with more information (e.g. eco-labelling), economic incentives and rewards ( $c f$. Defra, 2008). However, this approach proved to attain scarce and not durable results (Morris et al., 2012). Also, it has been recognised that behaviour is not always aligned with expressed pro-environmental values and attitudes. The 'value-action gap' ( $c f$. Blake, 1999) is a major shortcoming undermining the fundamental assumption embedded in these models of a linear relationship between personal values and behaviour, as well as the related possibility to modify consumers' behaviour by influencing their attitudes and values.

As a result, a growing body of academic literature has criticised the intrinsic problems and limitations of social psychological models of behaviour and called for more holistic theoretical perspectives grounded in social and technological theories of practices and transition (Shove, 2003, 2010). In particular, social practice theory has been advocated as an alternative position able to re- 
frame academic debate and policy approaches to behaviour change and sustainable consumption.

\subsection{Social practice theory}

Drawing on theories of practice ( $c f$. Bourdieu, 1977; Giddens, 1984; Reckwitz, 2002; Schatzki, 1996; Shove et al., 2012; Warde, 2005), social practice theory shifts the focus from individual behaviour and choice to practices and their emergent dynamics. In this theoretical framework, behaviours are considered observable expressions of social phenomena - 'practices-as-performance' - rather than outcomes of consumer attitudes, beliefs and other motivational factors. Consequently, a practice perspective aims at understanding social change by considering behaviours - i.e. performances of practices - in relation to their material, social and cultural contexts. As a result, changes in behaviour are meant to be achieved by targeting and intervening on the socially embedded underpinnings of action - the 'practices-as-entities' (Spurling et al., 2013).

In social practice theory, a practice (-as-entity) is defined as "a routinized type of behaviour which consists of several elements, interconnected to one other: forms of bodily activities, forms of mental activities, 'things' and their use, a background knowledge in the form of understanding, know-how, states of emotion and motivational knowledge" (Reckwitz, 2002: 249). Shove et al. (2012: 14) have grouped these components in three types - 'material', 'competence' and 'meaning' - arguing that: “in doing things like driving, walking or cooking, people (as practitioners) actively combine the elements of which these practices are made". Driving as a practice, for example, consists of cars, road infrastructures, systems of road signs, knowledge of road rules, driving skills, sets of images and ideas of what it means to drive a city car or a sports car, etc. Hence, a practice - a way of driving, walking or cooking "emerge[s], persist[s], shift[s] and disappear[s] when connections between elements of these three types are made, sustained or broken" (Fig. 1).

Configurations of elements making up practices are socially and culturally shared and vary across space and time, these being geographically and historically grounded (Kuijer and de Jong, 2012). Therefore, practices (-as-entities) have trajectories or paths of development (Warde, 2005), as habits and routines continually evolve and transform (Shove et al., 2012). Conceptions of normality and what are considered to be socially acceptable ways of living and doing change over time, as do practices. Accordingly, more or less

\begin{abstract}
Meaning: cultural conventions, expectations and socially shared
\end{abstract} meanings

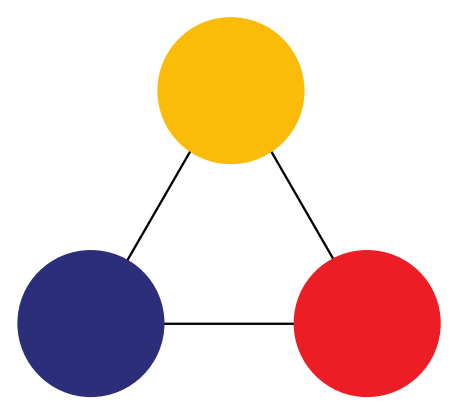

Material: objects, tools, infrastructures resource-intensive practices emerge and are reproduced, become dominant or disappear. Adopting practices as unit of analysis makes it possible to consider how (un)sustainable patterns of consumption come into being, take place and unfold, diffuse or die out.

Due to this capability to provide a broad view on social change, a practice perspective has been recently used to investigate energy consumption practices (e.g. Gram-Hanssen, 2008; Doyle and Davis, 2013) and has some untapped potential to inform policy strategies and interventions ( $c f$. Spurling et al., 2013). However, in some of its current formulations, social practice theory tends ultimately to overlook individual consumers, reducing them to "more or less faithful carriers or practitioners" (Shove et al., 2012: 63) routinely reproducing "what people take to be 'normal' ways of life" (Shove, 2003: 3). This view prompts a series of considerations around agency (i.e. the role of the individual) and, more importantly, it misses the point that conceptions of 'normality' are culturally and socially shared as much as personally negotiated. Conceivably, it is possible to envisage how social expectations and culturally constructed conventions (i.e. the 'meaning' element of practices) are mediated by and through personal traits and preferences.

\subsection{The role of values}

Models of consumer behaviour and theories of practice rest upon and support two different paradigms to conceptualise behaviour and change. Although more radical positions argue for the impossibility of merging and overcoming the divides ( $c f$. Shove, $2010,2011)$, academic research in the area of sustainability increasingly attempts to create a fruitful dialogue between these positions ( $c f$. Darnton et al., 2011; Whitmarsh et al., 2011; Wilson and Chatterton, 2011; Boldero and Binder, 2013). Following a similar direction, this paper combines social psychology and social practice theory to examine the role of values in the acceptance, adoption and diffusion of PSSs that enable collaborative consumption.

\subsubsection{Values in social psychology}

The refined theory of basic individual values of Schwartz et al. (2012: 664) defines values as "trans-situational goals, varying in importance, that serve as guiding principles in the life of a person or group". In social psychology, values are understood as motivational constructs located within individuals and translating into behaviours. In particular, values are often assumed to influence consumer behaviour and have a role in motivating proenvironmental behaviour and sustainable consumption (for a comprehensive literature review see Corner et al., 2014). In this area, a significant number of previous academic studies have utilised Schwartz's value theory ( $c f$. Schwartz, 1992, 1994) to measure personal values through the Schwartz Value Survey (SVS) (cf. Schwartz, 1992, 2006) and, later, the Portrait Value Questionnaire (PVQ) (cf. Schwartz, 2006; Schwartz et al., 2001) in either 40- or 21item versions. More recently, a refined version of the theory and a new measurement tool, the PVQ-R $3{ }^{2}$ were released. The refined theory, validated in 15 samples from 10 countries, is intended to be more accurate and able to provide better heuristic and explanatory power by accounting for 19 basic individual values instead of the original set of 10 (Schwartz et al., 2012) (Table 1).

In this model the 19 values are ordered in a circular motivational continuum (Fig. 2), arranged according to their compatibility or conflict and further grouped in four higher order values: openness to change (i.e. readiness for new ideas, actions and experiences) vs. conservation (i.e. self-restriction, order, and avoiding change); self-

Fig. 1. Elements and linkages sustaining practices. Adapted from Shove et al., 2012: 29; Spurling et al., 2013: 9.

\footnotetext{
${ }^{2}$ A 57-items revised version of the PVQ5X presented in Schwartz et al., 2012.
} 
Table 1

The 19 values in the refined theory, each defined in terms of its motivational goal (Schwartz et al., 2012: 669).

\begin{tabular}{|c|c|}
\hline Value & $\begin{array}{l}\text { Conceptual definitions in terms of motivational } \\
\text { goals }\end{array}$ \\
\hline Self-direction-thought & $\begin{array}{l}\text { Freedom to cultivate one's own ideas and } \\
\text { abilities }\end{array}$ \\
\hline Self-direction-action & Freedom to determine one's own actions \\
\hline Stimulation & Excitement, novelty, and change \\
\hline Hedonism & Pleasure and sensuous gratification \\
\hline Achievement & Success according to social standards \\
\hline Power-dominance & Power through exercising control over people \\
\hline Power-resources & $\begin{array}{l}\text { Power through control of material and social } \\
\text { resources }\end{array}$ \\
\hline Face & $\begin{array}{l}\text { Security and power through maintaining one's } \\
\text { public image and avoid humiliation }\end{array}$ \\
\hline Security-personal & Safety in one's immediate environment \\
\hline Security-societal & Safety and stability in the wider society \\
\hline Tradition & $\begin{array}{l}\text { Maintaining and preserving cultural, family, or } \\
\text { religious traditions }\end{array}$ \\
\hline Conformity-rules & $\begin{array}{l}\text { Compliance with rules, laws, and formal } \\
\text { obligations }\end{array}$ \\
\hline Conformity-interpersonal & Avoidance of upsetting or harming other people \\
\hline Humility & $\begin{array}{l}\text { Recognizing one's insignificance in the larger } \\
\text { scheme of things }\end{array}$ \\
\hline Benevolence-dependability & $\begin{array}{l}\text { Being a reliable and trustworthy member of the } \\
\text { ingroup }\end{array}$ \\
\hline Benevolence-caring & Devotion of the welfare of ingroup members \\
\hline Universalism-concern & $\begin{array}{l}\text { Commitment to equality, justice, and protection } \\
\text { for all people }\end{array}$ \\
\hline Universalism-nature & Preservation of the natural environment \\
\hline Universalism-tolerance & $\begin{array}{l}\text { Acceptance and understanding of those who are } \\
\text { different from oneself }\end{array}$ \\
\hline
\end{tabular}

enhancement (i.e. pursuing one's own interests) vs. selftranscendence (i.e. transcending one's own interests for the sake of others) (Schwartz et al., 2012: 669).

\subsubsection{Values in social practice theory}

Conversely, values are not explicitly addressed in current formulations of social practice theory. Hards (2011) offers one of the

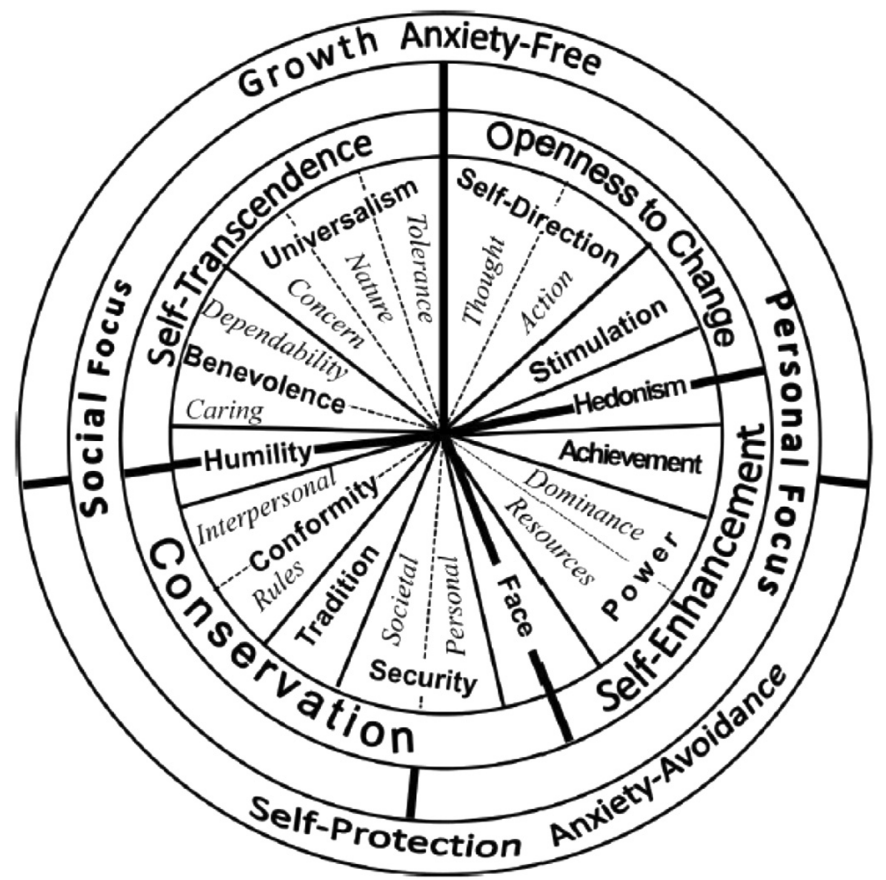

Fig. 2. Proposed circular motivational continuum of 19 values with sources that underlie their order (Schwartz et al., 2012: 669). few tentative accounts of how personal environmental values could be reconceptualised within a practice-based framework. Opposed to social psychological understandings of values as inherent properties of individuals, in a practice perspective values are seen as social constructs, expressions of cultural phenomena and ideas circulating within society. As such, they are part of configurations of elements that make up practices, limiting and enabling understandings and actions of their carriers. Values are, thus, situated: enabled and constrained by the diverse social contexts in which people operate.

Challenging the assumption of a causal relationship between values and behaviour (i.e. values preceding and translating into behaviour), values and practices are regarded as co-constructive, with personal values shaping and being shaped by, through and within performances of practices, contextual experiences and social interactions (Hards, 2011). The link between values and practices is dynamic, in so far as values are continuously changed, adapted and (re)produced in concrete social settings. As suggested by Evans (2007: 18): "values influence choices and practices but the choices and practices that are undertaken in actuality have the effect of (or at least the potential to) renegotiating values".

\subsubsection{Values as "proxies for meaning"}

While Hards (2011) provides an account of how social practices play a part in the evolution of personal environmental values, it remains uncovered how personal values, in turn, could have an influence on social practices. Building on the proposition by Hargreaves (2011: 87) that "values might be seen as proxies for meaning", this research project explores the possibility for personal values, located within the individual, to act upon the 'meaning' element (i.e. the bundle of cultural conventions, social norms, collective assumptions and expectations) of practices, thus contributing to (or hindering) the acceptance, adoption and diffusion of more or less sustainable practices and patterns of consumption.

Drawing on Shove et al. (2012), this view positions the carrier of a practice at the centre of the practice itself. Maintaining unchanged the original conceptualisation of practices, the proposed framework recognises the interaction between the carrier and a specific configuration of material, competence and meaning elements. In addition to connecting the elements together through the performance of that practice, it is contended that the carrier interacts and negotiates with each element (Fig. 3). This relationship (operating both ways) is mediated by personal traits, individual specificities and preferences. Conceivably, acceptance and engagement in a practice may result easier when the carrier's values are aligned with the 'meaning' element of the practice. On the contrary, their misalignment may cause resistance to that practice.

\section{Methodology}

Drawing on the possible complementarity between social psychology and social practice theory, the role of values in the context of collaborative consumption was explored through a mixed methods study. An explanatory sequential design ${ }^{3}$ was chosen to introduce, compare and contrast insights from Schwartz's theory of basic individual values in an examination of collaborative

\footnotetext{
3 "The Explanatory Sequential Design is a mixed methods design in which the researcher begins by conducting a quantitative phase and follows up on specific results with a second phase. The second, qualitative phase is implemented for the purposes of explaining the initial results in more depth" (Creswell and Plano Clark, 2011: 82).
} 

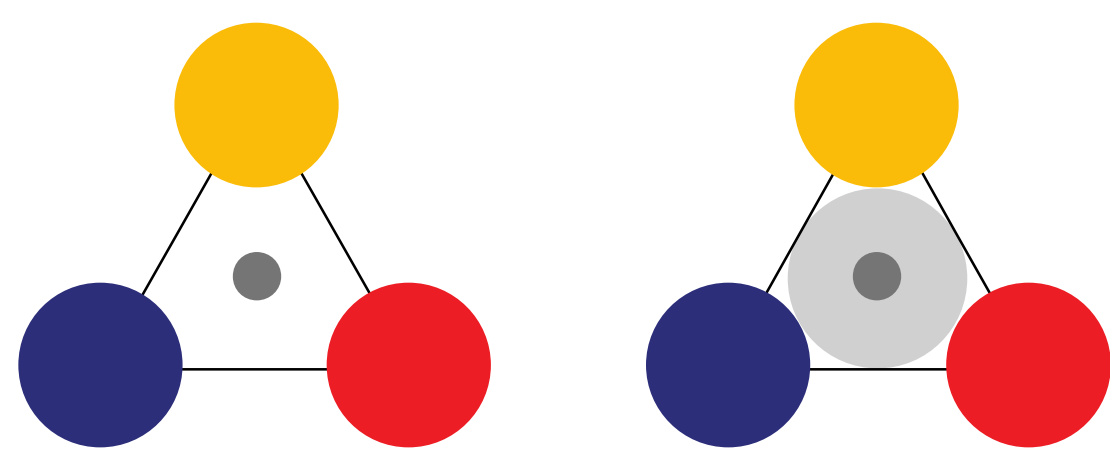

Fig. 3. Carrier (dark grey) and interaction (light grey) with elements of practice.

consumption informed by social practice theory. The investigation was structured in two subsequent and interactive phases: a quantitative data collection and analysis, followed by a qualitative strand of research. The initial quantitative study was carried out to measure individual values through use of Schwartz's PVQ-R3 tool. Results were followed up through semi-structured interviews facilitated by a series of visual prompts. Schwartz's 19 values were used as a starting point for investigating how people understand their values and relate them to different collaborative consumption practices.

\subsection{Ecomodo}

The research limited its scope to the case study of Ecomodo (www.ecomodo.com), a UK-based online marketplace through which people can lend and borrow each other's objects, spaces and skills either free of charge or for a small fee. The website is an example of a PSS based on sharing within a community, mediated by a service provider who retains a percentage on agreed monetary transactions. Essentially, Ecomodo enables users to list their items to lend and see what others have on offer to borrow. The platform additionally features some assurance mechanisms to help build

Table 2

Means (centred) and standard deviations of the 19 values.

\begin{tabular}{lll}
\hline Value & M (c) & SD \\
\hline Self-direction-thought & 5.04 & 0.65 \\
Self-direction-action & 4.71 & 0.68 \\
Stimulation & 3.82 & 1.04 \\
Hedonism & 4.07 & 0.78 \\
Achievement & 3.84 & 0.84 \\
Power-resources & 2.37 & 0.90 \\
Power-dominance & 2.86 & 0.83 \\
Face & 3.85 & 0.90 \\
Security-personal & 4.08 & 0.73 \\
Security-societal & 3.83 & 0.83 \\
Tradition & 2.98 & 0.91 \\
Conformity-rules & 3.39 & 1.08 \\
Conformity-interpersonal & 3.92 & 0.92 \\
Humility & 3.83 & 0.81 \\
Benevolence-dependability & 4.92 & 0.56 \\
Benevolence-caring & 4.91 & 0.73 \\
Universalism-concern & 5.06 & 0.68 \\
Universalism-nature & 4.79 & 0.92 \\
Universalism-tolerance & 4.87 & 0.72 \\
\hline
\end{tabular}

Means (M) and standard deviation (SD) are calculated from individual responses centred around each respondent's mean for all of the 57 value items in the questionnaire. To restore the range of the original scale, the overall respondents' mean is then added to the results. This correction, recommended by Schwartz et al. (2012), accounts for differences in the response scale use and converts absolute value scores into their relative importance in the value system. The means $M(c)$ hence reflect values priorities. confidence and trust. In particular, users can leave feedback and are able to control who can borrow from them by joining or creating trusted 'lending circles'. Also, lenders can request an insurance cover or a security deposit for their items.

Ecomodo was launched in March 2010 but still strives to become established. This appears mainly due to a difficulty in reaching the critical mass (of both listed items and active users) needed to work effectively. The situation, common to many collaborative consumption schemes, leaves a series of questions open about the feasibility of the model and the factors that determine commercial viability. As a consequence, there was considerable scope to investigate the possible role played by consumers' values in the acceptance of this potentially sustainable PSS, the motivations for adoption by its current users and the reasons for its failure in diffusion.

\subsection{Quantitative data collection and analysis}

This paper presents findings from the initial quantitative study conducted through an online survey administered to Ecomodo registered users. Their values were quantitatively assessed through the PVQ-R3 tool (see Section 2.3.1), a 6-point scale questionnaire complemented by additional demographic questions (i.e. age, gender, level of education, household income). Respondents were asked to indicate how similar the person portrayed in the questions was to themselves $(1=$ not at all like me; $2=$ not like me; $3=\mathrm{a}$ little like me; 4 = moderately like me; 5 = like me; 6 = very much like me). Respondents' values were inferred from the implicit values of the people they considered similar to themselves ( $c f$. Schwartz et al., 2012).

A link to the Schwartz's PVQ-R3 questionnaire was sent out in December 2012 through the Ecomodo monthly newsletter to 2340 subscribing users. A prize draw for two $£ 20$ gift vouchers was used as an incentive for participation. The responses collected were $N=93$ (attesting a $\sim 4$ response rate); however, 30 cases were excluded from the analysis after the dataset cleaning procedures. $N=63$ completed questionnaires were analysed with the IBM SPSS Statistics v.19 software. Data provided individual and aggregate scores for each of the 19 basic values measured (in Table 1), allowing the respondents' value priorities and orientation to be identified.

Table 3

Means (centred) of the four higher order values.

\begin{tabular}{ll}
\hline Value & $\mathrm{M}(\mathrm{c})$ \\
\hline Self-transcendence & 4.73 \\
Openness to change & 4.41 \\
Self-enhancement & 3.40 \\
Conservation & 3.70 \\
\hline
\end{tabular}


Table 4

Compared means (centred) and standard deviations of the original 10 basic individual values.

\begin{tabular}{llllll}
\hline & \multicolumn{2}{l}{ UK } & & \multicolumn{2}{l}{ Ecomodo } \\
\cline { 2 - 3 } \cline { 5 - 6 } & $\mathrm{M}(\mathrm{c})$ & $\mathrm{SD}$ & & $\mathrm{M}(\mathrm{c})$ & $\mathrm{SD}$ \\
\hline Self-direction* & 4.61 & 0.82 & & 4.87 & 0.52 \\
Stimulation & 3.60 & 1.01 & & 3.82 & 0.96 \\
Hedonism & 3.84 & 0.96 & & 4.07 & 0.71 \\
Achievement & 3.80 & 0.95 & & 3.84 & 0.80 \\
Power* & 3.27 & 0.83 & & 2.62 & 0.71 \\
Security* & 4.71 & 0.82 & & 3.96 & 0.61 \\
Tradition & 4.22 & 0.91 & & 2.98 & 0.90 \\
Conformity* & 4.07 & 0.94 & & 3.65 & 0.84 \\
Benevolence* & 5.09 & 0.63 & & 4.91 & 0.59 \\
Universalism* & 4.77 & 0.65 & 4.91 & 0.62 \\
\hline
\end{tabular}

Values labelled with ${ }^{*}$ are calculated by combining the multiple items measuring them in the PVQ-R3. For an explanation on the centring procedures see note Table 2.

Results were used to verify two assumptions, based largely on previous studies on the value antecedents of (self-reported) proenvironmental behaviour ( $c f$. Grunert and Jørn Juhl, 1995; Gutierrez Karp, 1996; Krystallis et al., 2008; Pepper et al., 2009; Shaw et al., 2005; Stern and Dietz, 1994; Thøgersen and Ölander, 2002):

a) Consumers engaging in collaborative consumption score higher on self-transcendence values (and, in particular, universalism) and openness to change values.

b) Consumers engaging in collaborative consumption score lower on self-enhancement and conservation values.

An additional supposition considered was the possible existence of a common salient value orientation in respondents attesting value priorities different from the general UK population, most of whom, it may be assumed, are not using Ecomodo.

c) Consumers joining Ecomodo demonstrate a value orientation that differs from value priorities measured in non-users.

In order to verify this possibility, responses from Ecomodo users were compared with data from the European Social Survey (ESS) ${ }^{4}$ Round 5 (2010/2011) collected by Ipsos MORI. As part of this research, Schwartz's PVQ-21 was administered as a supplementary questionnaire to $N=2422$ respondents considered representative of the population aged 15 or above living in the UK (European Social Survey, 2012). The ESS results were suitable for a tentative comparison with data from the Ecomodo sample, although the analysis was limited to the 10 original basic individual values (in Table 4).

\section{Results}

Ecomodo respondents were more likely to be female (32\% males, $68 \%$ females), white-British $(86 \%)$ well-educated ( $81 \%$ held a degree level), and middle aged (33\% aged $35-44,21 \%$ aged $45-54$ ). The majority were married or living as a couple (74\%), while $21 \%$ were single or never married. ${ }^{5}$ When asked to state the main reason for joining Ecomodo, one third of respondents stated 'to be green' (32\%). Other motivations were, in order of preference, 'to connect with my local community/lending circle' (27\%), 'to get

\footnotetext{
${ }^{4}$ The ESS is an academically-driven multi-country survey. Further information available at: http://www.europeansocialsurvey.org/.

${ }^{5}$ It has not been possible to verify if our sample is representative of the entire Ecomodo population; demographic information of new users is not collected as this is considered a potential barrier to entry.
}

more out of the things I own' (19\%), 'to save money' (17\%), and 'other' (5\%). None of the respondents signed up 'to give to a charity'.

According to the results shown in Tables 2 and 3, the expected condition (i.e. assumptions a, and b, above) are confirmed. Ecomodo respondents scored higher in self-transcendence (i.e. transcending one's own interests for the sake of others) and openness to change values (i.e. readiness for new ideas, actions and experiences) and lower in self-enhancement (i.e. pursuing one's own interests) and conservation values (i.e. self-restriction, order, and avoiding change). In aggregate, benevolence (i.e. preservation and enhancement of the welfare of people with whom one is in frequent personal contact) and universalism (i.e. understanding, appreciation, tolerance and protection for the welfare of all people and for nature) represent the sample respondents' main priorities, with universalism-concern and universalism-tolerance ranking better than universalism-nature. Moreover, the latter also has the highest standard deviation of the three items measured for universalism, suggesting that preservation of the natural environment varies in importance for Ecomodo users. Finally, the sample assigns its lower priorities to power values (i.e. social status and prestige, control or dominance over people and resources) and tradition, while stimulation and conformity-rules show the highest standard deviation among the values.

Results were then combined in the Schwartz's original 10 basic individual values and compared with data from the general UK population (i.e. non-users). The UK population appears to endorse tradition, security and power considerably more than Ecomodo users who, by contrast, consider self-direction, hedonism, stimulation and universalism to be more important as guiding principles in their lives. In terms of value priorities, however, both samples seem to assign more importance to benevolence and universalism values and least to power (Table 4).

In examining the results for the four higher order values (in Table 5), the comparison additionally revealed some interesting insights for the exploration of values in relation to collaborative consumption. With both the UK population and Ecomodo users scoring higher in self-transcendence and lower in selfenhancement, the inverted position of conservation and openness to change values may indicate that, on one side, Ecomodo users might be more willing to engage in new and challenging experiences because of their positive disposition towards change, excitement, stimulation and creativity. On the other side, the general UK population would rather tend to maintain the status quo, complying with social expectations and norms, and seeking for stability in society and relationships.

Finally, independent samples $t$-tests (in Table 6) were performed to determine if the two sets of data from the UK population and the Ecomodo sample were statistically significantly different in their variances (Levene's test) and means ( $t$-test). The null hypothesis that the variability of the two groups is equal ( $p$-value $<0.05$ ) is rejected for security, self-direction, hedonism and achievement, and the null hypothesis that means are equal $(p$-value $<0.05)$ is not rejected for conformity and benevolence values. Accordingly, the

Table 5

Compared means (centred) of the four higher order values.

\begin{tabular}{lll}
\hline & $\frac{\mathrm{UK}}{\mathrm{M}(\mathrm{c})}$ & $\frac{\text { Ecomodo }}{$\cline { 2 - 3 }} \\
\hline Self-transcendence* & 4.93 & $\mathrm{M}(\mathrm{c})$ \\
Openness to change* $_{\text {Self-enhancement* }}^{*}$ & 4.01 & 4.91 \\
Conservation* $^{*}$ & 3.64 & 4.25 \\
\hline
\end{tabular}

Values labelled with * are calculated by combining the multiple items measuring them in the PVQ-R3. 
Table 6

Independent samples test: inferential statistics.

Independent samples test

\begin{tabular}{|c|c|c|c|c|c|c|c|c|c|c|}
\hline & & \multicolumn{2}{|c|}{$\begin{array}{l}\text { Levene's test for equality } \\
\text { of variances }\end{array}$} & \multicolumn{7}{|c|}{$t$-test for equality of means } \\
\hline & & \multirow[t]{2}{*}{$\mathrm{F}$} & \multirow[t]{2}{*}{ Sig. } & \multirow[t]{2}{*}{$t$} & \multirow[t]{2}{*}{ df } & \multirow[t]{2}{*}{$\begin{array}{l}\text { Sig. } \\
\text { (2-tailed) }\end{array}$} & \multirow[t]{2}{*}{$\begin{array}{l}\text { Mean } \\
\text { difference }\end{array}$} & \multirow[t]{2}{*}{$\begin{array}{l}\text { Std. Error } \\
\text { difference }\end{array}$} & \multicolumn{2}{|c|}{$\begin{array}{l}95 \% \text { confidence interval } \\
\text { of the difference }\end{array}$} \\
\hline & & & & & & & & & Lower & Upper \\
\hline \multirow[t]{2}{*}{ Security } & Equal variances assumed & 9.380 & 0.002 & -4.679 & 2483 & 0.000 & -0.48323 & 0.10328 & -0.68574 & -0.28072 \\
\hline & Equal variances not assumed & & & -6.167 & 67.910 & 0.000 & -0.48323 & 0.07836 & -0.63959 & -0.32687 \\
\hline \multirow[t]{2}{*}{ Conformity } & Equal variances assumed & 1.651 & 0.199 & -1.302 & 2483 & 0.193 & -0.15538 & 0.11933 & -0.38938 & 0.07862 \\
\hline & Equal variances not assumed & & & -1.440 & 66.048 & 0.155 & -0.15538 & 0.10792 & -0.37085 & 0.06009 \\
\hline \multirow[t]{2}{*}{ Tradition } & Equal variances assumed & 0.015 & 0.903 & -8.494 & 2483 & 0.000 & -0.98116 & 0.11551 & -1.20765 & -0.75466 \\
\hline & Equal variances not assumed & & & -8.535 & 65.300 & 0.000 & -0.98116 & 0.11496 & -1.21072 & -0.75159 \\
\hline \multirow[t]{2}{*}{ Benevolence } & Equal variances assumed & 1.292 & 0.256 & 1.184 & 2483 & 0.237 & 0.09559 & 0.08075 & -0.06275 & 0.25393 \\
\hline & Equal variances not assumed & & & 1.261 & 65.735 & 0.212 & 0.09559 & 0.07583 & -0.05582 & 0.24700 \\
\hline \multirow[t]{2}{*}{ Universalism } & Equal variances assumed & 0.037 & 0.847 & 4.995 & 2483 & 0.000 & 0.41244 & 0.08257 & 0.25053 & 0.57434 \\
\hline & Equal variances not assumed & & & 5.214 & 65.580 & 0.000 & 0.41244 & 0.07910 & 0.25450 & 0.57038 \\
\hline \multirow[t]{2}{*}{ Self-direction } & Equal variances assumed & 14.282 & 0.000 & 5.134 & 2483 & 0.000 & 0.53151 & 0.10352 & 0.32852 & 0.73451 \\
\hline & Equal variances not assumed & & & 7.876 & 70.242 & 0.000 & 0.53151 & 0.06749 & 0.39692 & 0.66611 \\
\hline \multirow[t]{2}{*}{ Stimulation } & Equal variances assumed & 1.056 & 0.304 & 3.740 & 2483 & 0.000 & 0.47778 & 0.12776 & 0.22726 & 0.72831 \\
\hline & Equal variances not assumed & & & 3.895 & 65.562 & 0.000 & 0.47778 & 0.12268 & 0.23282 & 0.72275 \\
\hline \multirow[t]{2}{*}{ Hedonism } & Equal variances assumed & 6.777 & 0.009 & 4.019 & 2483 & 0.000 & 0.48494 & 0.12066 & 0.24834 & 0.72155 \\
\hline & Equal variances not assumed & & & 5.333 & 67.997 & 0.000 & 0.48494 & 0.09093 & 0.30349 & 0.66640 \\
\hline \multirow[t]{2}{*}{ Achievement } & Equal variances assumed & 4.141 & 0.042 & 2.449 & 2483 & 0.014 & 0.29291 & 0.11958 & 0.05842 & 0.52741 \\
\hline & Equal variances not assumed & & & 2.866 & 66.571 & 0.006 & 0.29291 & 0.10220 & 0.08889 & 0.49693 \\
\hline \multirow[t]{2}{*}{ Power } & Equal variances assumed & 2.832 & 0.093 & -3.845 & 2483 & 0.000 & -0.40503 & 0.10533 & -0.61158 & -0.19847 \\
\hline & Equal variances not assumed & & & -4.423 & 66.406 & 0.000 & -0.40503 & 0.09158 & -0.58784 & -0.22221 \\
\hline
\end{tabular}

two samples can be considered quite different in their scores and the analysis confirms the correctness of the previous descriptive observations. Assumption c, above, is thus confirmed.

\section{Discussion}

The quantitative study measured value priorities in 63 Ecomodo users. In keeping with previous studies on values and proenvironmental behaviour, the analysis identified a common value orientation towards self-transcendence (i.e. benevolence, universalism) and openness to change (i.e. self-direction, stimulation) over self-enhancement (i.e. achievement, power) and conservation values (i.e. security, tradition, conformity). However, the importance attributed to 'nature' (i.e. preservation of the natural environment) varies significantly among Ecomodo users and only one third of them indicated that they have joined Ecomodo 'to be green'. Lending and borrowing through this PSS is likely to address a number of other values.

The comparison between data from Ecomodo respondents and a representative sample of the UK population further proved the distinctiveness of the value orientation detected, which diverged from the one observed in the UK respondents. The main differences amongst the two groups were scored in Tradition, Security and Power (respectively of $1.24,0.75$ and 0.65 points), with the Ecomodo respondents scoring lower than the UK population for each of these three values. The results help to describe the role of values in the acceptance of collaborative consumption and explain possible reasons behind the unsuccessful introduction of this particular PSS.

Tradition (i.e. maintaining and preserving cultural, family, or religious traditions) seems to play against collaborative consumption insofar as it represents a continuation of the current state of affairs. On the contrary, the sharing economy - and, thus, PSSs that enable these alternative business models - are intrinsically disruptive of the status quo. The innovative solutions they propose often radically challenge mainstream conventions, displacing ingrained habits and well-established courses of actions. Security (i.e. safety in one's immediate environment and stability in the wider society) suggests the relevance of concepts such as reliability and trust in other people to collaborative consumption. By their own nature, collaborative consumption models rely on social connections and interactions between strangers. Hence building trust is essential for the sharing economy to thrive and, perhaps, serve as an engine for rediscovering neighbourhoods and local communities. Power (i.e. power through control of material and social resources) brings out issues of private ownership of material possessions. In many cases collaborative consumption involves individuals sharing their idle or underused possessions with each other. If a prerequisite for the existence of a number of these models is an end to exclusivity of use, this form of material attachment represents instead a real barrier to the acceptance of potentially sustainable PSSs such as Ecomodo.

\section{Conclusion}

The analysis of the unsuccessful case of Ecomodo in this research suggests that lending and borrowing through this PSS may be appealing only to a (still) limited number of consumers sharing a certain, distinct, value orientation. Therefore, individual values may be considered partly responsible for a failure in wider acceptance, adoption and diffusion of PSSs that enable collaborative consumption. However, it has been inferred that the actual influence of values can be better understood in relation to broader considerations of what it means to carry out certain practices (e.g. lending and borrowing) within society, how these practices are experienced and what kind of social interactions they put in place. For this reason, a subsequent strand of qualitative research, which will be presented in a following paper, further explored the possibility for values to act upon the 'meaning' element of practices (i.e. cultural conventions, expectations and socially shared meanings) in order to investigate the relationship between specific values and the engagement in collaborative consumption.

This paper focused on determining the values of Ecomodo users and the potential contribution from considering the 'meaning' 
element of practices to address the question of how consumers can influence the introduction and scaling up processes of sustainable PSSs. However, complementing this study with an account of the 'competence' and 'material' elements underlying collaborative consumption practices would provide a more detailed picture of the breadth and complexity of factors at stake. In particular, an analysis of the 'material' element would prove useful to uncover what is, and could be, the role played by design and how sustainable PSSs can be designed to foster user acceptance and adoption.

Finally, although consumer values might hinder or contribute to the acceptance, adoption and diffusion of collaborative consumption, innovative business models are likely to find other difficulties in becoming mainstream. Even when they are well received by larger audiences (e.g. Airbnb, Uber and BlaBlaCar), these propositions may still find additional barriers at the level of established systems of provision (i.e. the social and economic organisation of the delivery of products and services) and existing policy and legislation frameworks. Whereas combining insights from social psychology and social practice theory proves valuable to advance understandings of consumer behaviour and the social practices they engage in, system innovation theory and multi-level perspectives on sociotechnical change (cf. Tukker et al., 2008; Quist and Tukker, 2013) may be, in those cases, the appropriate territory for further exploration.

\section{Acknowledgements}

The authors would like to thank the Design Research Society for supporting part of this research through a DRS Student Research Bursary.

\section{References}

Blake, J., 1999. Overcoming the "value-action gap" in environmental policy: tensions between national policy and local experience. Local Environ. 4, 257-278.

Boldero, J.M., Binder, G., 2013. Can psychological and practice theory approaches to environmental sustainability be integrated? Environ. Plan. 45 (11), 2535-2538.

Bourdieu, P., 1977. Outline of a Theory of Practice. Cambridge University Press, Cambridge.

Botsman, R., Rogers, R., 2011. What's Mine is Yours. How Collaborative Consumption is Changing the Way we Live. HarperCollins, London.

Collier, A., Cotterill, A., Everett, T., Muckle, R., Pike, T., Vanstone, A., 2010. Understanding and Influencing Behaviours: a Review of Social Research, Economics and Policy Making in Defra [online]. Available at: http://archive.defra.gov.uk/ evidence/series/documents/understand-influence-behaviour-discuss.pdf (accessed July 2014)

Corner, A., Markowitz, E., Pidgeon, N., 2014. Public engagement with climate change: the role of human values. Wiley Interdiscip. Rev. Clim. Change 5 (3), $411-422$.

Creswell, J.W., Plano Clark, V.L., 2011. Designing and Conducting Mixed Methods Research, second ed. Sage, London.

Darnton, A., 2008. GSR Behaviour Change Knowledge Review. Reference Report: An overview of behaviour change models and their uses. Government Social Research, London [online]. Available at: http://www.civilservice.gov.uk/wpcontent/uploads/2011/09/Behaviour_change_reference_report_tcm6-9697.pdf (accessed February 2014)

Darnton, A., Verplanken, B., White, P., Whitmarsh, L., 2011. Habits, Routines and Sustainable Lifestyles: a Summary Report to the Department for Environment, Food and Rural Affairs. AD Research \& Analysis for Defra, London.

Defra, 2008. A Framework for Pro-environmental Behaviours [online]. Available at: https://www.gov.uk/government/uploads/system/uploads/attachment data/ file/69277/pb13574-behaviours-report-080110.pdf (accessed December 2013).

Doyle, R., Davies, A.R., 2013. Towards sustainable household consumption: exploring a practice oriented, participatory backcasting approach for sustainable home heating practices in Ireland. J. Clean. Prod. 48, 259-270.

European Social Survey (ESS), 2012. ESS5-2010 Documentation Report. The ESS data archive edition 3.0 [online]. Available at: http://www.europeansocial survey.org/docs/round5/survey/ESS5_data_documentation_report_e03_0.pdf (accessed February 2014).

Evans, D., 2007. Attitudes, Values and Culture: Qualitative Approaches to 'values' as an Empirical Category. RESOLVE Working Paper Series 04-07 [online]. Available at: http://resolve.sustainablelifestyles.ac.uk/publications/attitudesvaluesandcul turequalitativeapproachestovaluesasanempiricalcategory (accessed September 2012).
Giddens, A., 1984. The Constitution of Society. Outline of the Theory of Structuration. Polity, Cambridge.

Gram-Hanssen, K., 2008. Consuming technologies - developing routines. J. Clean. Prod. 16 (11), 1181-1189.

Grunert, S.C., Jørn Juhl, H., 1995. Values, environmental attitudes, and buying of organic foods. J. Econ. Psychol. 16 (1), 39-62.

Gutierrez Karp, D., 1996. Values and their effect on pro-environmental behaviour Environ. Behav. 28 (1), 111-133.

Hards, S., 2011. Social practice and the evolution of personal environmental values. Environ. Values 20, 23-42.

Hargreaves, T., 2011. Practice-ing behaviour change: applying social practice theory to pro-environmental behaviour change. J. Consum. Cult. 11 (1), 79-99.

Jackson, T., 2005. Motivating Sustainable Consumption: a Review of Evidence on Consumer Behaviour and Behavioural Change. Report to the 'Sustainable Development Research Network', London [online]. Available at: www. c2p2online.com/documents/MotivatingSC.pdf (accessed May 2012).

Krystallis, A., Vassallo, M., Chryssohoidis, G., Perrea, T., 2008. Societal and individualistic drivers as predictors of organic purchasing revealed through a portrait value questionnaire (PVQ)-based inventory. J. Consum. Behav. 7, $164-187$.

Kuijer, L., de Jong, A., 2012. Identifying design opportunities for reduced household resource consumption: exploring practices of thermal comfort. J. Des. Res. 10 (1 2), 67-85.

Manzini, E., Vezzoli, C., Clark, G., 2001. Product-service systems: using an existing concept as a new approach to sustainability. J. Des. Res. 1 (2).

Morris, J., Marzano, M., Dandy, N., O’Brien, L., 2012. Forestry, Sustainable Behaviours and Behaviour Change: Setting the Scene. The Research Agency of the Forestry Commission [online]. Available at: http://www.forestry.gov.uk/fr/INFD-923FBR (accessed December 2013).

Owyang, J., Samuel, A., Grenville, A., 2014. Sharing is the New Buying. How to Win in the Collaborative Economy [online]. Available at: http://www.visioncritical $\mathrm{com} /$ sites/default/files/pdf/sharing-new-buying-collaborative-economy-report. pdf (accessed June 2014).

Pepper, M., Jackson, T., Uzzell, D., 2009. An examination of the values that motivate socially conscious and frugal consumer behaviours. Int. J. Consum. Stud. 33 126-136.

Quist, J., Tukker, A., 2013. Knowledge collaboration and learning for sustainable innovation and consumption: introduction to the ERSCP portion of this special volume. J. Clean. Prod. 48, 167-175.

Reckwitz, A., 2002. Toward a theory of social practices. A development in culturalist theorizing. Eur. J. Soc. Theory 5 (2), 243-263.

Schatzki, T.R., 1996. Social Practice. A Wittgensteinian Approach to Human Activity and the Social. Cambridge University Press, New York.

Schwartz, S.H., 1992. Universals in the content and structure of values: theory and empirical tests in 20 countries. In: Zanna, M. (Ed.), Advances in Experimental Social Psychology, vol. 25. Academic Press, New York, pp. 1-65.

Schwartz, S.H., 1994. Are there universal aspects in the content and structure of values? J. Soc. Issues 50, 19-45.

Schwartz, S.H., 2006. Les valeurs de base de la personne: théorie, mesures et applications. Rev. Française Sociol. 47, 249-288.

Schwartz, S.H., Cieciuch, J., Vecchione, M., Davidov, E., Fisher, R., Beierlein, C., Ramos, A. Verkasalo, M. Lönnqvist, J., Demirutku, K. Dirilen-Gumus, O. Konty, M., 2012. Refining the theory of basic individual values. J. Personal. Soc Psychol. 103 (4), 663-688.

Schwartz, S.H., Melech, G., Lehmann, A., Burgess, S., Harris, M., Owens, V., 2001 Extending the cross-cultural validity of the theory of basic human values with a different method of measurement. J. Cross Cult. Psychol. 32, 519-542.

Shaw, D., Grehan, E., Shiu, E., Hassan, L., Thomson, J., 2005. An exploration of values in ethical consumer decision making. J. Consum. Behav. 4 (3), 185-200.

Shove, E., 2003. Changing Human Behaviour and Lifestyle: a Challenge for Sustainable Consumption? [online]. Available at: http://www.psi.org.uk/ehb/docs shove-changinghumanbehaviourandlifestyle-200308.pdf (accessed June 2014).

Shove, E., 2010. Beyond the ABC: climate change policy and theories of social change. Environ. Plan. 42 (6), 1273-1285

Shove, E., 2011. On the difference between chalk and cheese - a response to Whitmarsh et al's comments on 'Beyond the ABC: climate change policy and theories of social change'. Environ. Plan. 43, 262-264.

Shove, E., Pantzar, M., Watson, M., 2012. The Dynamics of Social Practice. Everyday Life and How it Changes. Sage, London.

Spurling, N., McMeekin, A., Shove, E., Southerton, D., Welch, D., 2013. Interventions in Practice: Re-framing Policy Approaches to Consumer Behaviour [online] Available at: http://www.sprg.ac.uk/uploads/sprg-report-sept-2013.pdf (accessed December 2013)

Stern, P., 2000. Towards a coherent theory of environmentally significant behaviour J. Soc. Issues 56 (3), 407-424.

Stern, P., Dietz, T., 1994. The value basis of environmental concern. J. Soc. Issues 50 (3), 65-84.

Thøgersen, J., Ölander, F., 2002. Human values and the emergence of a sustainable consumption pattern: a panel study. J. Econ. Psychol. 23 (5), 605-630.

Tukker, A., Tischner, U. (Eds.), 2006a. New Business for Old Europe: Product-service Development, Competitiveness and Sustainability. Greenleaf Publishing, Sheffield, UK.

Tukker, A., Tischner, U., 2006b. Product-services as a research field: past, present and future. Reflections from a decade of research. J. Clean. Prod. 14 (17), $1552-1556$. 
Tukker, A., Charter, M., Vezzoli, C., Sto, E., Munch Andersen, M., 2008. System Innovation for Sustainability I. Perspectives on Radical Change to Sustainable Consumption and Production. Greenleaf Publishing, Sheffield, UK.

Tukker, A., Cohen, M.J., De Zoysa, U., Hertwich, E., Hofstetter, P., Inaba, A., Lorek, S. Stø, E., 2006. The Oslo declaration on sustainable consumption. J. Ind. Ecol. 10, 9-14.

Vezzoli, C., Ceschin, F., Diehl, J.C., Kohtala, C., 2012. Why have 'Sustainable product-service Systems' not been widely implemented? Meeting new design challenges to achieve societal sustainability. J. Clean. Prod. 35, $288-290$.

Warde, A., 2005. Consumption and theories of practice. J. Consum. Cult. 5 (2), $131-153$.

Whitmarsh, L.E., O'Neill, S., Lorenzoni, I., 2011. Climate change or social change? Debate within, amongst, and beyond disciplines. Environ. Plan. 43, 258-261.

Wilson, C., Chatterton, T., 2011. Multiple models to inform climate change policy: a pragmatic response to the 'beyond the $\mathrm{ABC}^{\prime}$ debate. Environ. Plan. 43, $2781-2787$.

Please cite this article in press as: Piscicelli, L., et al., The role of values in collaborative consumption: insights from a product-service system for lending and borrowing in the UK, Journal of Cleaner Production (2014), http://dx.doi.org/10.1016/j.jclepro.2014.07.032 